\title{
Question And Answer Controller Composition (Qacc): A Technique for Developing Students' Writing Skill \\ By
}

Rekha Asmara, S.Pd., M.Pd.

Lecturer of English Language Education Study Program at FKIP UNISKI Kayuagung

Email: rekha.asmara@gmail.com

\begin{abstract}
This study aimed at investigating whether or not there was a significant difference in writing achievement between the students who were taught by using Question and Answer Controller Composition (QACC) technique and that of those who were not. A quasi-experimental method was conducted toward the eleventh grade students in Senior High School YPPG Tanjung raja in which forty-two students were involved as the sample which was divided into two groups. In collecting the data, a written test was administered. Before giving the test, the test was tried out to non-sample students in order to know its validity and reliability. Then, the data were analyzed using $t$-test through SPSS 16. The result showed that $t$-obtained was 4.788 at the significant level 0.05 and the critical value of t-table was 2.0211. Since t-obtained (4.788) was higher than t-table (2.0211) and $\mathrm{p}_{\text {value }}(0.000)$ was less than $\alpha_{\text {value }}(0.002)$, it could be concluded that the null hypotheses (Ho) was rejected and the research hypotheses $(\mathrm{Ha})$ was accepted. In other words, there was a significant difference in writing achievement between the students who were taught by using Question and Answer Controller Composition (QACC) technique and that of those who were not.
\end{abstract}

Key words: Question and Answer Controller Composition technique, report writing

\section{INTRODUCTION}

Learning English means learning its language components and skills. Language component contains grammar, vocabulary, pronunciation, and spelling. Whereas, language skill covers listening, speaking, reading, and writing. Here, writing, among other skills, is often considered as the most difficult skill to learn. Brown and Yule $(1983$, p.10) states that learning to write in the foreign language was often considered being one of the most difficult aspects of language learning for the teacher to help the students to develop the writing skill not merely so that they could pass examination but also for more general use when they wanted to use the English in the outside world. It implies that students need to increase their writing skill for many purposes in their life besides their school achievement. Outside school environment, they might deal with many works in written or printed forms.

Moreover, Negari (2011, p.299) claimed that writing in a second or foreign language seems to be the most difficult language skill for language learners to acquire in academic contexts. The difficulties in basic writing affect the learner's ability to write word with correct spelling, appropriate word choice, and basic mechanics such as letter formation, grammar, 
and punctuation. Therefore, the learners who are learning to write need much time and practice to develop their writing skill in teaching and learning process.

There are some problems in improving writing skill in teaching and learning process, especially students' interest, self confidence and activeness in learning writing English (Tiaranita, 2012:2). First, lack of interesting is the common problem which faces the students in learning English. Then, lack of self confidence is the second factor that reputed as key to give expression about something especially learning English in writing. Moreover, the students' passive is the last factor which becomes specific problem which has to give attention in learning English during teaching and learning process.

To overcome those problems, teachers can use various techniques of teaching writing skill. Question and Answer Controller Composition (QACC) technique was introduced in this study. QACC as a technique was beneficial for the teacher and students in English language teaching especially in teaching writing. Slamet (2003), in his research, found that QACC was very useful as one of the technique on teaching writing process. The QACC technique helps students to generate ideas to write down with a sense of direction or organization in their writing. This paper also demonstrated how the QACC technique could be applied in each stage of the writing process: pre-writing, writing, peer and teacher response.

\section{Research Question}

The problem of the study was formulated in the following question: "Is there any significant difference in writing achievement between the students who are taught by using Question and Answer Controller Composition (QACC) technique and that of those who are not?"

\section{LITERATURE REVIEW}

\section{Writing Concept and Its Process}

Harmer (2001:79) states that writing is a form of comunication to deliver thought or to express feeling through written form. Writing skill stimulates thinking, compels students to concentrate and organize their ideas, and cultivates their abilities to summarize, analyze, and criticize. In other words, writing reinforces learning, thinking, and reflecting on the English language. Thus, it is not easy to write because writing should be able to produce something new and can give you an idea or ideas to the reader through writing.

Writing is far from being simple matter of transcribing language into written symbols. It is a thinking process and demands conscious intellectual effort. Furthermore, Rooks 
(1998:15) states that the aim of writing is communication. When people write, they want to give their ideas and information to their readers. In all major fields of study, research, and business, it is extremely important for a person to be able to communicate well in writing. Moreover, writers rarely know the outset exactly what it is they are going to write because many ideas only revealed during the act of writing itself. In conclusion, writing is a person's ability to communicate information and ideas to someone, public, government. Moreover, writing was not only an activity of arranging words into form of sentences_but also when people wrote, they should organize some interesting stuffs, which were experiences or ideas in written form.

The process of writing incorporates writing skills from the very beginning of the English learning process. Process writing focused on allowing students - especially young learners - to write with plenty of room left for error. During the process, a stage may be skipped but can be returned to later. There are five stages of the writing process, namely; prewriting, drafting, revising, editing, and publishing (Tomkins, 2004, p.10).

- Prewriting: Prewriting is a planning stage for writing. Planning is an important step of the writing process; it allows the writers to organize their writing before they even begin. Teachers might help students who have a difficulty in determining a topic using various strategies such as, graphical editing, free writing, and associative writing (Kapka, 2001, p.28).

- Drafting: In the draft stage, students are expected to put the arrangement they did in the planning stage on to paper. In this stage, spelling rules for the written text are ignored.

- Revising: This stage consists of the students' review of the written draft, sharing the draft text with a writing group that is formed in the classroom, and rearranging the content according to feedback from friends in the writing group. Revising is a difficult stage for students (Kapka, 2001, p.28).

- Editing: Until this stage, the focus is on the content. In this stage, spelling rules and punctuation, which are called the mechanical aspect of writing, are checked. Before sharing what they have written with others, the students review the draft for the last time and make corrections for readability. An editing checklist might be prepared illustrating the spelling errors. The students might benefit from this list for their learning in the future. Different evaluation materials might be used in teaching students about the third and fourth stages. 
- Publishing: This is the last stage of the writing process. In this stage, the students share the text they have written with the readers they determined in the prewriting stage. What is important here is that teacher makes writing meaningful for student.

\section{Question and Answer Controller Composition (QACC) Technique and Its Benefits}

Question and Answer Controller Composition (QACC) technique is one of the important techniques for teaching writing skill because QACC could help students to improve their writing skills by controlling their emotion to write something. It is important for teacher to help students establish an internal reader to respond to at each phase just as the natural writing. Current views on the highly able stress the importance of recognize their existing writing skills, which are often sophisticated, and of developing their further. Questioning can develop their thought process and guide their investigations, stimulate and sustain their curiosity and motivation, also lead them to consider new ideas and take risks.

In general principle for teaching writing, Byrne (1993, p.21) claims that there are four key approaches to teaching writing. i.e.: focus on accuracy, focus on fluently, focus on text and focus on purpose. On the other hand, Raimes (1983, p.78) states that there are six approaches to teaching writing in ESL classes that is the controlled - to-free approach, the free writing approach, the paragraph pattern approach, the grammar-syntax or organization approach, communicative approach and the process approach. In relation to this view, Question and Answer Controller Composition is a technique in using controlled writing which uses the controlled - to-free approach and focus on accuracy. It is a good method of reinforcing grammar, vocabulary and syntax in context.

Exactly, Raimes (1983, p.96) defines that Question and Answer Controller Composition is the type of controlled composition that uses a question and answer format allows students a little more freedom structuring sentences. They are not given the actual text that they will write rather they are given a series of questions. The answer to which form the text. This view indicates that Question and Answer Controlled Composition (QACC) is a good follow-up exercise to a reading passage. In the classroom, students read or listen to a passage two or three times. Then, without further reference to the passage, they wrote a composition based on a given set of questions about the materials they had just studied. These tasks provide an excellent opportunity for teachers to tie language study, with the study of other school subjects. 
Controlled composition may be considered as one of suitable ways, particularly in facilitating the beginners and intermediate students who study English as a foreign language to write. In controlled composition tasks, more exercises are given to the students an outline to complete, a paragraph to manipulate, a model to follow or a passage to continue. It will give them help as they go along, correcting grammar, supplying an idiom and suggesting a new word. There are some benefits of controlled composition proposed by Reid and Linstrom (1985, p.87) cited in Slamet (2003);

1) Controlled composition is a useful tool at all levels of writing cases,

2) Controlled composition teaches the students basic sentence and paragraph skill, 3) Controlled composition allows the students to become more aware of and to practice pre-writing and revision strategies, 4) Controller composition gives the students opportunity to assimilate and improve the organization skills necessary to write good composition, 5) Controlled composition concentrates on writing assignment rather than the theories of writing, 6) Controlled composition gives the students step-by-step approach to the various processes involved in writing composition, and 7) At the last stage controlled composition gives the students opportunity to write about topics of individual interest.

Those benefits could improve the quality of the technique because it could make the students write something easily in composition and could improve student's ability in writing skill. In conclusion, controlled composition was a good technique to reinforce the students in using the convention of written English such as indentation, punctuation, connecting words and spelling. It also gave them practice in developing paragraph.

\section{Procedures of Teaching Using QACC Technique}

The following were the procedures of teaching English writing skill through Question and Answer Controller Composition (QACC).

\section{Pre-Activities}

- The teacher greeted the students.

- The teacher asked the students some questions related to the topic.

\section{Whilst-Activities}

- The teacher explained Question and answer (QA) and Controller Composition (CC) to the students to develop their imagination and creativity of them.

- The teacher explained the students how to apply the Question and Answer to be a good passage and after that the teacher controlled the students in writing composition.

- The teacher explained the students how to write report text by using QACC. 
- The teacher gave the students a series of question and cues of answer to which formed a passage.

- The teacher asked the students to write report text based on question and answer format of the QACC which were given before.

\section{Post-Activities}

- The teacher asked the students to collect their work and discuss it.

- The teacher concluded the lesson.

\section{METHODS}

Quasi-experimental method was applied. Creswell (2005, p.297) describes that Quasi-experiment includes assignment, but not random assignment of participants to groups. There were an experimental group and a control group which were both given a pre-test and post-test. The sample was selected by means of purposive sampling. McMillan (1996, p.92), defines that in purposive sampling (sometimes referred to as purposeful, judgment, or judgmental sampling), the researcher selects particular elements from the population that will be representative or informative about the topic. Therefore, from the three classes available in the population, two classes consisting of 42 students were taken as the sample of this study.

A written test was administered for both groups as pre- and post-tests to collect the data. The test was given to the students in order to know the students' achievement in writing. In the test, the students were asked to choose one of the writing topics given. However, before giving the test to the sample students, the test had been tried out to thirty five non-sample students of class XI IA 1 at senior high school number 1 Tanjung Raja to find out its validity and reliability. The results had indicated that the writing test was valid and reliable to be used as the instrument. In addition, the data obtained from the writing test were scored by two assigned raters using rubric for writing. The scores were then statistically analyzed using t-test analysis through SPSS $16^{\text {th }}$ version.

\section{RESULTS AND DISCUSSION}

\section{Results of the Pre- and Post-Tests in Experimental and Control Groups}

The scores obtained by the students in writing test were tabulated. In experimental group, the lowest score in the pre-test was 6 , the highest score was 18 , and the mean score was 12.28. Whereas, in the post-test, the lowest score was 12 , the highest score was 20 , and the mean score was 15.04. Furthermore, in control group, the lowest score in the pre-test was 8 , the highest score was 16 , and the mean score was 11.04. Meanwhile, in the post-test, the 
lowest score was 6 , the highest score was 16 , and the mean score was 11.28. The score distribution is presented in the following table.

Table 1

The Distribution of Pre- and Post-Tests Scores in Experimental and Control Groups

\begin{tabular}{|c|c|c|c|c|c|c|c|c|c|}
\hline \multirow{3}{*}{$\begin{array}{l}\text { Score } \\
\text { Range }\end{array}$} & \multirow{3}{*}{ Category } & \multicolumn{4}{|c|}{ Frequency } & \multicolumn{4}{|c|}{ Percentage } \\
\hline & & \multicolumn{2}{|c|}{$\begin{array}{c}\text { Experimental } \\
\text { Group }\end{array}$} & \multicolumn{2}{|c|}{ Control Group } & \multicolumn{2}{|c|}{$\begin{array}{c}\text { Experimental } \\
\text { Group }\end{array}$} & \multicolumn{2}{|c|}{ Control Group } \\
\hline & & $\begin{array}{l}\text { Pre- } \\
\text { Test }\end{array}$ & $\begin{array}{c}\text { Post- } \\
\text { Test }\end{array}$ & $\begin{array}{l}\text { Pre- } \\
\text { Test }\end{array}$ & $\begin{array}{c}\text { Post- } \\
\text { Test }\end{array}$ & $\begin{array}{l}\text { Pre- } \\
\text { Test }\end{array}$ & $\begin{array}{c}\text { Post- } \\
\text { Test }\end{array}$ & $\begin{array}{l}\text { Pre- } \\
\text { Test }\end{array}$ & $\begin{array}{c}\text { Post- } \\
\text { Test }\end{array}$ \\
\hline $16-20$ & $\begin{array}{l}\text { Very } \\
\text { Good }\end{array}$ & 5 & 6 & 2 & 2 & $23.80 \%$ & $28.57 \%$ & $9.52 \%$ & $9.52 \%$ \\
\hline $10-15$ & Good & 13 & 15 & 12 & 14 & $61.90 \%$ & $71.42 \%$ & $57.14 \%$ & $66.67 \%$ \\
\hline $5-9$ & Fair & 3 & - & 7 & 5 & $14.28 \%$ & - & $33.33 \%$ & $23.80 \%$ \\
\hline $0-4$ & Poor & - & - & - & - & - & - & - & - \\
\hline
\end{tabular}

\section{Statistical Analyses Results}

\subsection{The Statistical Analyses on the Experimental Group by Using Paired-Samples T-Test}

From the result of paired statistic of the experimental group, the mean of pre-test was 12.2 with standard deviation of 3.25 , whereas the mean of the post-test was 15.0 with standard deviation of 2.41 . The results of paired sample difference of writing achievement skill in means between pre-test and post-test of experimental group was 2.76. Standard deviation 3.59 and the value of t-obtained was 3.525 with df 20 the critical value of t-table 2.080. Since the value of t-obtained was higher than critical value of t-table: $3.525>2.080$, it meant that there was a significant difference in students' writing skill before and after the treatment using QACC technique. See table 2 below.

Table 2

\begin{tabular}{|c|c|c|c|c|c|c|c|c|}
\hline \multicolumn{9}{|c|}{ Paired Samples T-Test } \\
\hline & \multicolumn{5}{|c|}{ Paired Differences } & \multirow[b]{3}{*}{$\mathrm{t}$} & \multirow[b]{3}{*}{$\mathrm{df}$} & \multirow[b]{3}{*}{$\begin{array}{l}\text { Sig. }(2- \\
\text { tailed) }\end{array}$} \\
\hline & \multirow[b]{2}{*}{ Mean } & \multirow{2}{*}{$\begin{array}{c}\text { Std. } \\
\text { Deviation }\end{array}$} & \multirow{2}{*}{$\begin{array}{l}\text { Std. Error } \\
\text { Mean }\end{array}$} & \multicolumn{2}{|c|}{$\begin{array}{l}\text { 95\% Confidence Interval of the } \\
\text { Difference }\end{array}$} & & & \\
\hline & & & & Lower & Upper & & & \\
\hline $\begin{array}{l}\text { posttestexp - } \\
\text { pretestexp }\end{array}$ & 2.76190 & 3.59033 & .78347 & 1.12761 & 4.39620 & 3.525 & 20 & .002 \\
\hline
\end{tabular}


Based on the results of analysis obtained from the pre-test and post-test in experimental group, it was found that there was a significant difference in students' writing achievement before and after they were taught by using Question and Answer Controller Composition. It could be interpreted that using Question and Answer controller Composition technique in teaching writing could make the students easily to find out the ideas in details dealing with the information they knew before they wrote in the form of good text. Moreover, the technique enables the students to share the ideas with their classmates and they did not worry about what they would create and arrange in their texts so that their quality of writing could be achieved.

\subsection{The Statistical Analysis on the Control Group by Using Paired Samples T-Test}

From the result of paired sample of control group, the mean of pre-test was 11.0 with standard deviation of 2.39 whereas the mean of the post-test was 15.0 with standard deviation of 2.41. The result of paired sample difference of writing achievement skill in means between pre-test and post-test of control group was 4.00. Standard deviation 2.98 and value of tobtained were 6.144 with df 20 the critical value of t-table 2.080. Since the value of t-obtained was higher than critical value of t-table: $6.144>2.080$ it could be concluded that there was a significant difference in students' achievement before and after being taught writing by using explanation technique (conventional ones). The result of paired sample t-test in control group been seen in the following table.

Table 3

Paired Samples Test

\begin{tabular}{|c|c|c|c|c|c|c|c|}
\hline \multicolumn{5}{|c|}{ Paired Differences } & \multirow[b]{3}{*}{$\mathrm{t}$} & \multirow[b]{3}{*}{$\mathrm{df}$} & \multirow[b]{3}{*}{ Sig. (2-tailed) } \\
\hline \multirow[b]{2}{*}{ Mean } & \multirow[b]{2}{*}{ Std. Deviation } & \multirow{2}{*}{$\begin{array}{l}\text { Std. Error } \\
\text { Mean }\end{array}$} & \multicolumn{2}{|c|}{$\begin{array}{l}95 \% \text { Confidence Interval of } \\
\text { the Difference }\end{array}$} & & & \\
\hline & & & Lower & Upper & & & \\
\hline 4.00000 & 2.98329 & .65101 & 2.64202 & 5.35798 & 6.144 & 20 & .000 \\
\hline
\end{tabular}

Based on the results of analysis of the pre-test and post-test in control group, it was found that there was a significant difference in students' writing achievement before and after they were taught by using explanation method. It was shown that teaching writing by using explanation method was also effective and could improve the students' writing achievement. 


\subsection{The Difference Analysis on the Experimental and Control Groups}

From the result of independent sample t-test through SPSS version 16, the mean score of the post-test in experimental group was 15.04 with standard deviation of 2.41 whereas the mean score of the post-test in the control group was 11.28 with standard deviation of 2.66. The analysis of the data showed that difference value between mean score of post-test experimental group and mean score of post-test in control group was 3.76 at the significant level $p>0.05$ in two tailed testing with df 40 , the critical value of t-table was 2.0211. It was found that the value of t-obtained (4.788) was higher than the value of t-table (2.0211) and the Pvalue $(0,000)$ was lower than the $\alpha$ value $(0.05)$, the null hypotheses (Ha) was rejected and the research hypotheses (Ha) was accepted. It meant that there was a significant difference in students' writing skill between the students who were taught by using Question and Answer controller Composition technique and that of those who were not. See table 4 below.

Table 4

Independent Samples Test

\begin{tabular}{|c|c|c|c|c|c|c|c|c|c|c|}
\hline & \multicolumn{2}{|c|}{$\begin{array}{l}\text { Levene's Test } \\
\text { for Equality of } \\
\text { Variances }\end{array}$} & \multicolumn{7}{|c|}{ t-test for Equality of Means } \\
\hline & & \multirow[b]{2}{*}{$\mathrm{F}$} & \multirow[b]{2}{*}{ Sig. } & \multirow[b]{2}{*}{$\mathrm{t}$} & \multirow[b]{2}{*}{ df } & \multirow{2}{*}{$\begin{array}{l}\text { Sig. (2- } \\
\text { tailed) }\end{array}$} & \multirow{2}{*}{$\begin{array}{c}\text { Mean } \\
\text { Difference }\end{array}$} & \multirow{2}{*}{$\begin{array}{l}\text { Std. Error } \\
\text { Difference }\end{array}$} & \multicolumn{2}{|c|}{$\begin{array}{l}95 \% \text { Confidence } \\
\text { Interval of the } \\
\text { Difference }\end{array}$} \\
\hline & & & & & & & & & Lower & Upper \\
\hline \multirow[t]{2}{*}{ posttest } & $\begin{array}{l}\text { Equal } \\
\text { variances } \\
\text { assumed }\end{array}$ & .314 & .578 & 4.788 & 40 & .000 & 3.76190 & .78564 & 2.17406 & 5.34975 \\
\hline & $\begin{array}{l}\text { Equal } \\
\text { variances not } \\
\text { assumed }\end{array}$ & & & 4.788 & 39.622 & .000 & 3.76190 & .78564 & 2.17359 & 5.35022 \\
\hline
\end{tabular}

Based on the results of analysis between the post-tests in experimental group and control group, it was found that there was a significant difference in the students' writing achievement between the students who were taught by using Question and Answer Controller Composition and that of those who were not. It showed that Question and Answer controller Composition could help the students to explore the ideas easily. It happened because the students were interested in doing Question and Answer Controller Composition technique. Before the students wrote the report text, they had to write down their ideas which they brainstormed one by one on the white board in front of the class and asked some questions dealing with the ideas. Besides, Question and Answer Controller Composition technique 
could make the students be able to improve their vocabularies so that they could arrange their ideas in writing report text easily.

However, because of both of improvement existed in both groups, it could be said that teaching technique was not the only one factor which could improve achievement of the students. There were some other factors found during this study. First, most of the students in control group joined the English club in their school; second, most of the students in control group also learned English in outside school like training or course. Besides these facts, during the teching and learning process, students in control group tended to give more attention, good attitude, and appreciation to the researcher that they considered as their new teacher. Hence, these factors might increase their achievement in writing test even though they were not taught using QACC.

\section{CONCLUSION}

After analyzing the results of the paired samples t-test within groups (experimental and control groups), it was found that there were significant differences in writing achievement of the students in both groups. Then, the results of independent samples t-test showed that the Null Hypotheses (Ha) was rejected and the research hypotheses (Ha) was accepted in this study which meant that there was a significant difference in writing achievement between the students who were taught using QACC and that of those who were not. It was proved by the evidence that the value of t-obtained (4.788) was higher than the value of t-table (2.0211) and the Pvalue (0.000) was lower than the $\alpha_{\text {value }}(0.05)$.

\section{REFERENCES}

Brown, G., \& Yule, G. (1983). Discourse analysis. New York, NY: Cambridge University Press.

Byrne, A. (1993). Teaching writing skills. London: Longman.

Cresswell, J. W. (2005). Educational research: planning, conducting, and evaluating quantitative and qualitative research. New Jersey: Pearson Prentice Hall.

Harmer, J. (2001). The practice of English language teaching (3rd ed.). Harlow: Longman.

Kapka, D., \&Oberman, D. A. (2001). Improving students' writing skills through the modeling of the writing process. Research project, ERIC ED, 45 (5) 453-536.

McMilan, J. H. (1996). Educational research: Fundamental for the consumer. Virginia: Harper Collins Publishers. 
Negari, G. M. (2011). A study on strategy instruction and efl learners' writing skill. International Journal of English Linguistics Vol. 1, No.2. Available (online) on www.ccsenet.org/ijel.

Raimes, A.(1983). Technique in teaching writing. Oxford: Oxford University Press.

Rooks, G. M. (1998). Paragraph power communicating ideas through paragraph. Englewood $X$ Cliffc, NJ: Prentice Hall, Inc.

Slamet, M. (2003). Improving the second year students' writing skill in narrative paragraph through question and answer controller composition, writing composition. Unpublished Master's Thesis). (online) Available at http://projectgradehouse.org. Accessed on April 15th, 2013.

Tiaranita. (2012). Improving the ability in writing simple sentences through scrabble games for the first grade students of SMP Muhammadiyah 1 Godean. Unpublished Undergraduate Thesis. Faculty of Teacher Training and Education. Yogyakarta: University of Ahmad Dahlan.

Tompkins, G. E. (2004). Teaching writing: balancing product and process. Upper Saddle River, NJ: Merrill/Prentice Hall. 